\author{
Robert Phillipson \\ Copenhagen Business School, Denmark
}

\title{
LANGUAGE CHALLENGES IN GLOBAL AND REGIONAL INTEGRATION ${ }^{7}$
}

Summary. The article analyses whether the expansion of English is adding to linguistic repertoires, or whether a process of linguistic capital dispossession of national languages is taking place. It explores the role that discourses of 'global English' and of English as a 'lingua franca' play in processes of global and regional European integration. It considers whether the linguistic capital of all languages can be made productive when in much of Europe there is a marked downgrading of the learning of foreign languages other than English, alongside the continued neglect of many minority languages. Language pedagogy and language policy need to be situated within wider political, social and economic contexts. EU schemes for research collaboration and student mobility are of limited help in maintaining linguistic diversity. The Bologna process furthers European integration but intensifies the hegemony of English. Nordic universities are moving into bilingual education, combining English with a national language. The 2006 Declaration on a Nordic Language Policy aims at ensuring that Nordic languages and English develop in parallel, that all residents can maintain their languages, and that language policy issues should be widely understood. If neoliberalism and linguistic neoimperialism are determining factors, there are challenges in maintaining the vitality of languages, and organizing school and university education so as to educate critical multilingual citizens.

Keywords: Bologna process; EU; global English; language policy; lingua franca; linguicism; linguistic capital; linguistic imperialism; Nordic languages; Winston Churchill.

It is important to situate language in education policy within a historical context so as to clarify the forces behind the shifting mosaic of languages in a country and its education system. The ideal of facilitating the emergence of wellqualified schoolchildren is currently up against constraints that affect enlightened policies negatively and that are limiting the autonomy of universities and academic freedom.

Pierre Bourdieu, probably the most influential social scientist in Europe in the twentieth century, reckons that scholars have three choices:

\footnotetext{
${ }^{7}$ The text is a conversion into written form of the plenary lecture delivered at Sustainable Multilingualism 2017 conference in Kaunas, Lithuania. Some key references have been included; for more detail please refer to my List of Publications on www.cbs.dk/eng/staff/rp.msc.
} 
- $\quad$ as an expert serving societal needs as these are understood by the politically and economically powerful, i.e. undertaking commissioned research;

- as professors trapped in esoteric, erudite scholarly isolation, remaining in a specialised ivory tower;

- $\quad$ as scholars who intervene in the political world in the name of the values and truths achieved in and through autonomy and academic freedom (Bourdieu, 1989, p 486) ${ }^{8}$.

These three options may well overlap and reinforce each other, but it is helpful to be aware of the existential importance of epistemological, methodological, and political determinants that affect academics. In my own view we can, by drawing on research in radical sociolinguistics, in holistic language policy and planning, and in critical pedagogy, be committed professionally and socio-politically in the sense of Bourdieu's third option, which is what I aim at.

Bourdieu also, in a debate on language policies for a democratic Europe, "Quelles langues pour une Europe démocratique?", suggests how one can use English without being colonised linguistically and culturally (2001, p. 46, 48): "How can we counteract the abuse of power that is intrinsic to linguistic hegemony? (...) we need to reflect on this model so as to see if and how it is possible to go along with using English without the risk of being anglicised into its conceptual structures, without being brainwashed by its linguistic patterns. ${ }^{9 \prime}$

\footnotetext{
${ }^{8}$ L'alternative est claire, en effet, bien qu'elle soit très rarement perçue : ou bien accepter l'une ou l'autre des fonctions sociales que la nouvelle définition sociale impartit aux producteurs culturels, celle de l'expert, chargé d'assister les dominants dans la gestion des "problèmes sociaux", ou celle du professeur, enfermé dans la discussion érudite de questions académiques; ou bien assumer efficacement, c'est-à-dire avec les armes de la science, la fonction qui fut remplie longtemps par l'intellectuel, à savoir d'intervenir sur le terrain de la politique au nom des valeurs ou des vérités conquises dans et par I'autonomie. (Bourdieu, 1989, p. 486).

${ }^{9}$ On ne peut donc poser le problème de I'hégémonie anglaise sans poser le problème de I'hégémonie américaine ... I'universel, qui en d'autres temps et de façon tout aussi abusive, parlait en français ou en allemand ou japonais. L'impérialisme peut donc imposer des objets de pensée. Et il faut réfléchir sur ce modèle pour voir si et comment il est possible d'accepter l'usage de l'anglais sans s'exposer à être anglicisé dans ses structures mentales, sans avoir le cerveau lavé par les routines linguistiques.
} 


\section{Researching linguistic inequality and injustice}

One way of approaching the expansion of English is to ask whether its increased use is adding to our linguistic repertoires, or whether there is currently a process of linguistic capital dispossession of national languages taking place. If much of higher education and research in, say Denmark or Norway, entails the use of English, is this no threat to Danish or Norwegian as scholarly languages, or are these languages being downgraded and eliminated from functions that hitherto have been undertaken in them? In more scientific terms, is what is happening linguistic capital accumulation, an additive process in language learning and language use, or not? Expanding the linguistic repertoire of the individual and the group can be seen as linguistic capital accumulation. Foreign language learning is normally additive, but in several senses English in much of continental Europe has already become more than a foreign language because of its widespread domestic use. This is a complex question, because all languages evolve, and borrow lexical items and novel concepts from other languages.

On the other hand, if the adoption of English entails the replacement of discourses and functions that have hitherto been the preserve of a national language, dispossession may occur. Linguistic capital dispossession means that a dominant language replaces another language for specific functions, in academia, commerce or private life.

Similar structures and processes are involved in basic education when language acquisition and use take place at the expense of other languages, typically mother tongues. This is known in the bilingual education literature as subtractive language learning.

It is possible to identify key agents, external and internal, that are responsible for instigating and implementing the structures and ideologies (in Bourdieu's terms, the habitus) that cause dispossession. This was categorized by Louis-Jean Calvet as glottophagie (linguistic cannibalism), when analyzing how French was eliminating African languages during colonisation. John Swales has described English in academia as a lingua tyrannosaura. My own preference, inspired by the writings and activities of Gandhi, Frantz Fanon, and Ngũgĩ wa Thiong'o, is to describe English as a lingua frankensteinia, when its 
use has fatally destructive consequences for other languages. It is important to recognize that such linguistic imperialism is nothing intrinsic to any particular dominant language (whether English, Russian, or Spanish), but has to do with the uses to which such languages are put.

Whether linguistic capital accumulation or dispossession is occurring is an empirical question for exploration in any given context. Answering this question requires analysis of key characteristics of linguistic imperialism and of relevant data for clarifying the issue. As examples of when it could be important to undertake such research, consider:

- in Denmark, whether an excessive concentration on learning English in schools entails a significant loss in the learning of other foreign languages, leading to their de facto elimination;

- in Singapore whether the educational policy in using English as the exclusive medium of instruction has led to the replacement of ancestral languages, from China, India and Malaysia, by English in the home as well as in professional life;

- that in a higher education institution in Italy which decided to replace Italian by English in their courses, litigation has determined that this is in conflict with several clauses in the Italian constitution, with suggestions for language policies to be followed so that the institution acts legally ${ }^{10}$;

- in EU institutions, whether the gradual establishment of English as the dominant in-house language, replacing French, which had this role earlier, is at the expense of German, Spanish, and Italian as well as all other EU official languages. Speakers of Baltic and central European languages have felt that their languages are second-class in the EU system.

The current thrust behind "global" English means that Goethe's advocacy of multilingualism and Weltliteratur (in the sense of texts in all languages enriching humanity and the individual) has been replaced, in my view, by a naive endorsement of World English as though other languages are valueless. One senses that in Europe and other parts of the world there is a shift from Goethe's:

${ }^{10}$ ITALY Linguistic battle sparks revolt against globalization, Rosemary Salomone 10 March 2017. University World News Global Edition, Issue 450. Retrieved from http://www.universityworldnews.com/article.php?story=20170307132621476. 
Wer fremde Sprachen nicht kennt, weiss nichts von seiner eigenen.

Whoever knows no foreign languages knows nothing of their own language.

to

Wer English kennt, braucht nichts von andere Sprachen. Whoever knows English has no need of other languages.

The current focus in universities on economic constraints, internationalisation, and league tables of universities and publications (bibliometric quantification, ranking journals and publishers hierarchically) is symptomatic of this trend to privilege English and the concomitant academic culture of the English-speaking countries. While the content of scholarship is intrinsically universal, to assign a monopoly to English is to invalidly conflate language and science (Tonkin, 2011, Phillipson, 2011). This misguided ideology is intensified by considerable conceptual muddle in language policy work, for instance when terms like domain loss, lingua franca, and global are used without specification of how they should be understood, a point that I return to later in this article.

My claims about scholarly writings being deficient need some empirical documentation. I consider that there are serious flaws in how some influential British academics promote English-medium teaching in European higher education (for detail and references see Phillipson 2015 and 2016a). Jim Coleman in a survey article in Language Teaching in 2006 claims that there is a consensus about the likelihood of global diglossia with English as the exclusive language of science: "it seems inevitable that English, in some form, will definitely become the language of higher education" in Europe (italics added, RP). Likewise, David Graddol and David Crystal tend to endorse an expansion of English uncritically on the basis of unreliable data (see exemplification below).

By contrast a German former Minister of Education is worried about covert language policy driven by market forces: 'Contrary to the wording affirmed in the Bologna Declaration, the reform of higher education serves the purpose of replacing the linguistic and cultural diversity of Europe by an English linguistic monopoly' (Meyer, 2011), which tallies with my own analysis of the way the Bologna process serves to strengthen English 
(Phillipson, 2006). Many of the activities of the European Commission also serve to strengthen English at the expense of other languages (Phillipson, 2016b). For instance, English is at the summit of a hierarchy of languages on the Commission's website. Over the past 40 years, English has progressively become the default in-house language and virtually the exclusive language for communication with the wider world. Applications for research funding discriminate in favour of scholars for whom English is the primary scholarly language, at the expense of other languages, which could be a Romance, Slavic, or Finno-Ugric language. The evaluation process is exclusively in English. All such processes intensify English linguistic hegemony, which is in conflict with the EU rhetoric of strengthening multilingualism.

Another example. A High Level group on the Modernisation of Higher Education reported to the European Commission in June 2013. Recommendation 12 endorses English as the language of internationalisation, i.e. the sole international lingua academica. This shows how leading academic 'experts' have internalized this largely unquestioned hegemonic practice. All of these examples demonstrate the workings of linguicism. This has been defined as "ideologies, structures and practices which are used to legitimate, effectuate, regulate and reproduce an unequal division of power and resources (both material and immaterial) between groups which are defined on the basis of language" (Skutnabb-Kangas, 2000).

Whether linguicism is in place in any given context - international, national, or institutional - is an empirical question that needs documentation and analysis. For centuries, privileging a single national language in European countries and attempting to impose monolingualism in the dominant language was the norm in France, Spain, Great Britain and elsewhere. This ideological principle was extended to colonial empires. Belief in monolingualism, nationally and internationally, had its academic champions (the spin doctors of the time), in Spain (Nebrija), in France (Rivarol), and in the British empire (Macaulay).

Linguistic imperialism entails the following (Phillipson, 1992, 2009):

- It interlocks with a structure of imperialism in culture, education, the media, communication, the economy, politics, and military activities.

- In essence, it is about exploitation, injustice, inequality, and a hierarchy that privileges those able to use the dominant language. 
- It is structural: more material resources and infrastructure are accorded to the dominant language than to others.

- It is ideological: beliefs, attitudes, and imagery glorify the dominant language, stigmatise others, and rationalise the linguistic hierarchy.

- The dominance is hegemonic, it is internalised and naturalised as being "normal" in processes of supply and demand, push and pull forces.

- $\quad$ This entails unequal rights for speakers of different languages.

- Language use is often subtractive, proficiency in the imperial language and in learning it in education involves its consolidation at the expense of other languages.

- It is a form of linguicism, analogous to sexism, racism, and classism.

- $\quad$ Linguistic imperialism is invariably contested and resisted.

Linguistic imperialism has been widespread: in the suppression of regional languages (Welsh, Kurdish, ...), in colonial education promoting European languages and neglecting local languages, and in policies of the World Bank, British Council, and La Francophonie that fund support for European languages only in former colonies. Additional interlocking factors are the projection of Western models of education as being universally relevant, and as culturally and linguistically 'neutral'; implicit language policies that leave it to market forces to determine hierarchies of language, for instance in the EU system; monolingual native speakers of English posing as experts on language learning, even if they may lead monolingual lives and have never learned a foreign language successfully (Phillipson, 2016c). Also of significant ideological impact is the way English is being promoted as a "lingua franca" as though it ensures equality in communication.

\section{Discourses of 'global English' and of 'English as a lingua franca'}

Is "global English" a myth or a reality? If it exists, what are its essential features, granted that under one-third of the world's population have any proficiency in English? Should one rather see global English as a project that some interests and forces would like to achieve? Is an increased use of English 
marketed as a panacea for education worldwide, or should one rather see it as a pandemic?

In my view, it is important to see English in terms of identifiable products (activities, budgets, uses, writings etc.), facilitated by specific processes (learning time in schools, use for specific functions, including research, implementation of laws for language use in official functions and the media, university and school curricula worldwide, choice of language for international organizations, etc.) and as a project with identifiable agendas and agents (advocacy of English in government policies of the UK, USA, and Australia, and by elites worldwide, etc.). Connecting these three constituents presupposes an understanding of the forces behind changes in global and local linguistic conditions, building on the historical origins of the expansion of English. Analysis should assess where language policy is heading, nationally and internationally, including what the implications and consequences of the expansion of English are for other cultures and languages (Phillipson, 2016d).

"English was in the right place at the right time. (...) The English language has already grown to be independent of any form of social control". These bald statements are made by an eminent British linguist, David Crystal, in his English as a global language (1997). The first statement is ahistorical, trivialises the issue of language dominance, and ignores centuries of imperialism, first British and later American. The second statement is not one that one would expect from a linguist, who knows that standardised languages are normative, which is why dictionaries and grammars exist. In addition, international intelligibility presupposes a common lexico-grammatical and phonetic core of English as used by privileged groups in primarily the UK and USA. This need is greater in written English than in much spoken English. My review article on Crystal's book (Phillipson 1999) sees it as fundamentally triumphalist, an endorsement of the project to establish English globally, with false claims about the product and social processes involved.

There are similarities in how the advance of English throughout the British empire was legitimated in India in the 1830 s and by an influential 'international expert' on India in 2010. The overall thrust in what is written is fundamentally similar (see Table 1 ): 
Table 1.

Macaulay's and Graddol's insights on legitimization of English

\begin{tabular}{|l|l|}
\hline Macaulay's Minute $\mathbf{1 8 3 5}$ & Graddol's English Next India $\mathbf{2 0 1 0}$ \\
\hline It denigrates and stigmatises the local. & Indian learning of English is inadequate. \\
\hline It glorifies Western culture and English. & $\begin{array}{l}\text { English is the key to success in the } \\
\text { modern world. }\end{array}$ \\
\hline $\begin{array}{l}\text { It rationalises the asymmetrical } \\
\text { relationship between coloniser and } \\
\text { colonised. }\end{array}$ & $\begin{array}{l}\text { The UK has the solution to India's } \\
\text { language in education problem. }\end{array}$ \\
\hline A British intellectual can decide matters. & $\begin{array}{l}\text { A single expert from the UK can cover } \\
\text { the issues. }\end{array}$ \\
\hline $\begin{array}{l}\text { It conceals the economic interest of the } \\
\text { colonisers. }\end{array}$ & $\begin{array}{l}\text { The potential benefits to the UK economy } \\
\text { are not mentioned. }\end{array}$ \\
\hline $\begin{array}{l}\text { It fails to refer to the reality of British } \\
\text { military occupation of India. }\end{array}$ & $\begin{array}{l}\text { Geostrategic political and military } \\
\text { interests are not considered relevant. }\end{array}$ \\
\hline
\end{tabular}

Macaulay's declared goal was to produce 'interpreters between us and the many millions we govern'. His 'Minute' was about priorities in the short term as well as long-term goals. It was concerned exclusively with higher education, but the policy of giving priority to English had a major influence at all levels of education in British colonies. Graddol (cf.2010) has written several impressive studies for the British Council on the role of English in the modern world, and how to strengthen the British English Language Teaching (ELT) industry. He was commissioned to write a study of how English could be learned more effectively in India. This study brings in a set of myths that seem plausible but can easily be disproved:

- $\quad$ English as a global language. This should be seen as a project that some are attempting to bring about, in particular the British Council, working on behalf of the British government. Global English is not a present-day reality except in restricted circles.

- $\quad$ English is 'the language of business across Europe'. In fact, many languages are used in business in Europe.

- $\quad$ European universities are shifting from local languages to English. What continental European universities are doing is adding English to their repertoires. There is currently no evidence that this is at the expense of local languages of scholarship.

- $\quad$ There is a global consensus on how English should be learned, 'a new global orthodoxy'. Elsewhere in the report Graddol endorses the idea of 
a mix of educational approaches being needed, but the notion that one approach is universally valid is false.

- $\quad$ The early start fallacy. The age factor is one among many variables that influence educational success, but age is less important than the qualifications and quality of teachers, and choice of the most appropriate medium of instruction.

Graddol's work lends a veneer of academic respectability to the expansion of British ELT in India and elsewhere. This is an ambivalent role, because the British Council now derives over $80 \%$ of its huge income from ELT activities (teaching, testing, and consultancy). It is increasingly managed by people with business world experience through 'corporate plans' for income expansion. British 'soft power' now has a rock-hard economic and geopolitical thrust that is integral to neoliberalism, corporate globalisation, and British military activity. Cultural diplomacy and foreign 'aid' have never been innocent or altruistic.

That English is not global or universal is shown persuasively in a study of publications in the field of biodiversity conservation. A research project at the University of Cambridge identified 75,513 scientific manuscripts on biodiversity conservation on Google Scholar (Amano, González-Varo, and Sutherland, 2016).

The number of articles in the top languages was:

$\begin{array}{ll}\text { English } & 48,600 \text { (which is 64.4\%) } \\ \text { Spanish } & 9,520 \\ \text { Portuguese } & 7,800 \\ \text { Chinese } & 4,540 \\ \text { French } & 2,290\end{array}$

The valid conclusion from this study is that the notion that in the scientific world, everything of importance is published in English is simply incorrect and limits the quality of scientific work. German, Japanese, and Russian are also important languages of science. A second conclusion is that scholars who function exclusively in English are not optimally qualified. This is definitely true in the language policy field and in educational research.

A separate issue, which is also of relevance to 'Global Science', is how knowledge of the way biodiversity is understood and conserved in nonWesternised parts of the world, in indigenous knowledge culture and 
cosmology. The sustainability of our world is dependent on cherishing the multilingualism that has been evolved over centuries and millennia, in synergy with cultural and biological diversity.

A further example of active resistance to English linguistic imperialism can be found in the writings of scholars based in continental Europe, who are often proficient in several languages, and who denounce the rhetoric that labels English as a lingua franca for international scholarship:

the English used as an international scientific language is not a lingua franca, a non-language. English is a completely normal language with its specific monolingual semantics, like all other languages. [...] It is the bearer, like all other natural languages, of a particular vision of the world. As such it is not universal and purely objective, which is what real lingua francas were. (Trabant, 2012)

'English as a Lingua Franca' (ELF) is a field of study that has become fashionable among some applied linguists. They have chosen to study English when used by people for whom it is not their first language. A revealing book in this spirit is New perspectives on English as a European lingua franca by Heiko Motschenbacher (2013). On the basis of a limited spoken language corpus, it generalises about communicative and linguistic traits, and concludes that ELF is detached from native English norms of language and AngloAmerican cultural values. She cites ELF gurus: Jenkins ('international academic communication is today hardly ever native communication'), Seidlhofer (people can operate with their own 'common sense' criteria), and Widdowson ('the old conditions of relevance and appropriateness no longer apply'). This implies that ELF can do without any of the vocabulary, syntax, or phonology that has evolved in the UK, USA and elsewhere. It is also typical of ELF empiricist studies that their examples are drawn exclusively from speech, and written English is ignored, but this does not deter ELF converts from drawing bold conclusions about the English language.

There have been many denunciations of the theoretical weaknesses and pedagogical irrelevance of ELF (by, among others, Ian Mackenzie, Gibson Ferguson, François Grin, and Martin Kayman). The most powerful critique, drawing on a wealth of critical social theorists, is by John O'Regan, 'English as a lingua franca: an immanent critique', in Applied Linguistics in 2014. 
He reveals how ELF misrepresents the role of forms of English, reifying and hypostatizing them in theoretically invalid ways that ignore key social variables and socio-political realities. ELF misrepresents the diversity of English in globalization.

This research activity is an empiricist dead end. The ELF movement deludes teachers of English with false promises of what it is important to know about the use of English in the modern world. This criticism does not apply to scholarly work done in relation to English for Special Purposes, English for Academic Purposes (especially if translation is integrated into this), nor does it apply to Business English as a Lingua Franca, which has a strong tradition in several continental European countries, e.g. Piekkari and Westney 2017. For applied linguistics, I see O'Regan's analysis as having a comparable importance to Chomsky's denunciation of Skinnerian behaviorism in 1959.

A further problem with describing English as a lingua franca is that this generally seems to imply that the language is intrinsically a neutral instrument for 'international' communication between speakers who do not share a mother tongue. While English can of course serve many useful, informal purposes in this way, this understanding of the term may mislead one into believing that lingua franca English is disconnected from the many purposes it serves in key societal domains. English can be more accurately related to distinct contexts of use. It can and does function as a pre-eminent international lingua economica (in business and advertising, a principal though not exclusive language of corporate neoliberalism), a lingua emotiva (the imaginary of Hollywood, popular music, consumerism and hedonism), a lingua academica (in research publications, at international conferences, and as a medium for content learning in higher education), and a lingua cultura (rooted in the literary texts of English-speaking nations that school foreign language education traditionally aims at, and integrates with language learning as one element of general education). English is a major lingua bellica (the USA with military activities worldwide, 350 bases and 800 military facilities in 130 countries, NATO not only active in Europe but worldwide in the dubious 'war on terror'). English is also a major lingua politica in international organizations such as the United Nations and the European Union. The worldwide presence of English as a lingua americana is due to the massive 
economic, cultural and military impact of the USA. English functions in each of the categories indicated here.

I consider that describing English loosely as a lingua franca is pernicious if the language in question is a first language for some people but for others a foreign language. It is also misleading if the language is supposed to be neutral and disconnected from culture. It is a false term for any language that is taught as a subject in general education. There is also an ironic historical continuity in that the origin of the term was the need in the Middle East to describe the language of western European Christian crusaders many centuries ago. They spoke a wide range of mother tongues and were seen as Franks. Lingua franca was later used as a term for limited commercial transactions in the eastern Mediterranean and spoken ad hoc by people drawing on several languages. No lingua franca in this sense was ever codified. Now, by contrast, if lingua franca is used in relation to English, it is to a national language of several countries which is not a limited, partial language but the dominant language for the many functional purposes that are specified above. Scholarship on the international use of English ought to be concerned with all of the relevant functions that English serves, and the possible relevance for learners with a variety of mother tongues.

\section{English in continental Europe}

Can investment in the linguistic capital of several languages be made productive when in much of Europe there is a marked downgrading of the learning of foreign languages other than English, along with the continued neglect of many minority languages? To answer this question, it is necessary to analyse the reasons for the worldwide expansion of English over the past five centuries. In addition to the extensive British Empire, of both settler economies (North and Central America, Australasia, South Africa) and exploitation economies (in the rest of Africa and in Asia), USA exceptionalism in the past and present has been decisive. This is because since the time of George Washington the USA has been explicitly projected as 'a rising empire'. Presidents from Calvin Coolidge in 1925 to Donald Trump now have acted on the principle that 'The chief business of the American people is business'. 
President Harry Truman made it clear in 1947 that 'The whole world should adopt the American system. The American system can survive in America only if it becomes a world system". This was reaffirmed by President Barack Obama in 2014. "Here's my bottom line: America must always lead on the world stage." (for sources and more detail see Phillipson, 2014, 2016d, 2017.)

The first conference on 'The use of English as a world language' was held in 1934 in New York, with Carnegie Foundation funding. Agreement was reached on the goal of 'spreading English "as a world language" on a basis of UK-US collaboration' (italics added, RP). This led to US funding of activities on both sides of the Atlantic in the 1930s and again in the 1950s, and the creation of departments of applied linguistics and the English Language Teaching profession/industry. The key professional organizations - TESOL in the US, and IATEFL in the UK - were initially national bodies, but now project themselves as 'global'. This presupposes that the professional expertise in question is universally relevant, which is opportunist and fundamentally incorrect, not least as regards its relevance in foreign language learning. The traditions of learning English effectively as a foreign language in continental Europe were excluded from the Anglo-American English learning paradigm. This is monolingual and monocultural, ignoring contrastive analysis of the source and target language, and excluding translation. It is based on five fallacies (see Phillipson 1992, chapter 7). The very influential language proficiency tests (Cambridge, TOEFL, IELTS, etc.) suffer from the same weaknesses.

Linguistic imperialism operates either as imposition or as a hegemonic supply and demand affair, with many contributory push and pull factors. That its expansion serves the interests of the UK and USA is incontestable. Leading politicians have been well aware of the importance of an active language promotion policy, among them Winston Churchill in a speech at Harvard University, 6 September 1943). The power to control language offers far better prizes than taking away people's provinces or lands or grinding them down in exploitation. The empires of the future are the empires of the mind.

This gift of a common tongue is a priceless inheritance, and it may well one day become the foundation of a common citizenship. I like to think of British and Americans moving about freely over each other's wide estates with hardly a sense of being foreigners to one another. But I do not see why we should not try to spread our common language even more widely throughout the globe 
and, without seeking selfish advantage over any, possess ourselves of this invaluable amenity and birthright.

This was one of five themes in his speech, the others being UK/US unity, military collaboration, plans for global peace-keeping, and ensuring US/UK global dominance. Language policy interlocks with each of these. The close links between the UK and US are known in the UK as a 'special relationship', but there is no doubt about the British being subordinate to US power. The US had limited influence in global affairs after the First World War, and President Roosevelt was determined that this should change after the Second. He stated in 1942: 'We have profited by our past mistakes. This time we shall know how to make full use of victory' to conquer enemies and allies alike.

All British Prime Ministers have accepted US dominance. A Margaret Thatcher Center for Freedom was housed for many years at the extreme rightwing nationalist Heritage Foundation in Washington DC. The Thatcher centre had as its goal to ensure that the US and UK can 'lead and change the world'. The Foundation has deleted information about the Center from its website, but a new centre is being established in the UK to further the neoliberal AngloAmerican goals that she stood for ${ }^{11}$.

It is, of course, a truism that English can be used to resist and combat imperialism as well as to establish it, but the context of the major expansion of English has been as an integral constituent of global finance capital and commerce. English learning is now prominent in school education in many parts of the world, including Europe, and has an increased role in higher education. The UK and USA generally see themselves as monolingual countries, despite the considerable linguistic diversity in their territories and many minority groups. Continental Europe by contrast is becoming a form of bilingualism with English as the key foreign language. As a consequence, other foreign languages are being downgraded. This is a worrying development, since it limits access to the diversity of different cultural universes, in demographically large and in small countries. It is also important to recall Bourdieu's advice that English should be used without subordination to its conceptual universe, embedded in

11 https://www.thatchercentre.com. 
its linguistic forms. French scholars warn against 'la pensée unique', a single way of understanding the world.

This is a challenge that Scandinavia and Finland, the Nordic countries, are conscious of. These countries have a strong tradition of education leading to high levels of proficiency in several foreign languages, particularly English, French, and German. Language policy has been evaluated extensively in recent years. The main concern of this process, in academic and political circles, has been to assess whether the increased use of English represents a threat to the national, unifying language in each country. The overall goal has invariably been to plan for the continued vitality of national languages, while simultaneously evolving greater competence in English. There has unfortunately been much less focus on maintaining the vitality of a broader range of foreign language learning. The key Nordic declaration on language policy (Nordic Council of Ministers 2006) addresses means for achieving these goals. It encourages higher educational institutions to develop explicit language policy plans, and to make all residents in their countries aware of their language rights.

A Report on parallel language competence in Nordic universities was published in 2017 in Danish, and in 2018 in English by the Nordic Council of Ministers: More parallel, please!: Best practice of parallel language use at Nordic Universities: 11 recommendations. The recommendations build on years of experience in analyzing the evolution of English-medium instruction while ensuring that all functions that the national language has fulfilled in academia are maintained (in Danish, Finnish, Icelandic, Norwegian, and Swedish), and ensuring that 'international' staff and students develop academic competence in this language alongside English. It is a recipe for raising language awareness, counteracting linguicism effectively (following Bourdieu), and ensuring a reciprocal dialectic between the national language and English. I summarise the Recommendations for universities in the five Nordic countries as follows.

1. All universities should have a language policy integrated with its internationalisation policy and that relates to national language policy parameters and the role of the university locally.

2. All universities should have a language policy committee that follows developments continually. 
3. A language centre should, on the basis of research criteria, elaborate courses in the local language of relevance for 'international' staff and students and should ensure the quality of such courses; it should also offer translation and language revision services; it should develop digital resources.

4. International teaching and research staff should be instructed in forms of parallel academic language use, and features of local students' dialogue; they should also be familiarised with the local language of university administration; and progressively acquire competence to function fully in the local language; this should be stipulated in their employment contract.

5. There should be needs analysis in relation to study disciplines and future employment for guest students and for foreign students doing an entire degree; local students should be instructed in the discourse of their academic field in their language and in English, and ideally in additional languages.

6. Elaboration of a specialised needs analysis so as to achieve full parallel competence.

7. Criteria for choice of the language(s) of instruction, for lecturers' language proficiency, reading material, and specification of achievement in each language are needed.

8. Principles for the language of university administration.

9. Strategies for languages of publication.

10. Policies for research dissemination and popularisation nationally and internationally.

11. Elaboration of relevant digital tools for staff and students.

It is too early to be able to assess how far these recommendations will be implemented effectively. It is significant that they aim to ensure that English will not be seen as superior to national languages, and that these will be used by all staff, including 'international' staff. For foreign academics employed in Danish universities in the 1970s and 1980s, this went without saying. Becoming competent in Danish was imperative. There is now a need for this practice to be revived - even for recruits from 'English-speaking' countries!

What is manifestly absent is any consideration of the need in each country to have high-level research and teaching in a range of foreign languages, from Europe and elsewhere. This is a weakness that a different 
statement by Churchill anticipates when, in a speech in Copenhagen in 1950, he pleaded for universities to maintain their traditional virtues:

The first duty of a university is to teach wisdom, not to train, and to confirm character and not impart technicalities. We want a lot of engineers in the modern world, but we do not want a world of engineers. We want some scientists, but we must make sure that science is our servant and not our master... No amount of technical knowledge can replace the comprehension of the humanities or the study of history and philosophy.

The advantages of the nineteenth century, the literary age, have been largely put aside by this terrible twentieth century with all its confusion, exhaustion, and bewilderment of mankind. This is a time when a firm grip on all the essential verities and values of humanity and civilization should be the central care of the universities of Europe and the world.

These essential verities and values have been elaborated in a wide variety of languages and cultures. They are at risk in the neoliberal postChurchill world: his engineers have been replaced by economists, whose capitalist tunnel vision has created a world of indefensible, inhumane global and local inequalities. Capitalism creates winners and losers, internationally (USA, China, Germany, ...) and nationally (classes). Movements for political, social, and linguistic justice have achieved some success, but democracy and human rights principles are currently being weakened in many parts of the world (Skutnabb-Kangas and Phillipson, 2017). The EU has some major accomplishments, but is constitutionally committed to neoliberalism, with devastating effects (Greece, southern Europe) and weak language rights commitments (institutionally, in EU 'actions', and in language policy recommendations) (Phillipson, 2003).

As scholars, we should, following Bourdieu, integrate our teaching and research into sociopolitical activism. In language policy and language education, think globally and multilingually, while also acting locally, strengthening the language vitality of all languages, including revitalizing minority languages. Linguistic diversity in education systems should be entrenched. Linguistic wealth exists in a wide range of scholarly languages.

While we may be pessimistic in much of our analysis, there are grounds for optimistic and effective action. It is admirable that a conference on sustainable multilingualism announces plenaries in two languages, and 
organizes parallel sections in Lithuanian, French and German, so that English does not have an inequitable monopoly at 'international' conferences.

\section{References}

Amano, T., González-Varo, J. P., \& Sutherland, W. J. (2016). Languages Are Still a Major Barrier to Global Science. PLoS Biol, 14(12): e2000933. doi: 10.1371/journal.pbio.2000933.

Bourdieu, P. (1989). La noblesse d'état. Grandes Écoles et esprit de corps. Paris: Les Éditions de Minuit.

Bourdieu, P., De Swaan, A., Hagège, C., \& Fumaroli, M. et Immanuel Wallerstein (2001). Quelles langues pour une Europe démocratique? Raisons politiques, 2001/2.

Crystal, D. (1997). English as a global language. Cambridge Cambridge University Press.

Ferguson, G. (2009). Issues in researching English as a lingua franca: a conceptual enquiry. International Journal of Applied Linguistics, 19/2, 117-135.

Gazzola, M. \& Grin, F. (2013). Is ELF more effective and fair than translation? An evaluation of the EU's multilingual regime. International Journal of Applied Linguistics, 23/1.

Graddol, D. (2010). English Next India. British Council: The English Company (UK) Ltd. Retrieved from https://www.britishcouncil.in/sites/default/files/english_next_india__david_graddol.pdf.

Mackenzie, I. (2012). English as a lingua franca in Europe: bilingualism and multicompetence. International Journal of Multilingualism, 9/1, 83100.

Meyer, H. J. (2011). Bologna oder Harvard? Realität und Ideologie bei der deutschen Studienreform. Zeitschrift für Politik, Sonderband, 4, 5162.

Motschenbacher, H. (2013). New perspectives on English as a European lingua franca. Amsterdam: John Benjamins. 
Nordic Council of Ministers (2006). Deklaration om Nordisk Språkpolitik, København: Nordisk Ministerråd. Published in eight Nordic languages and English. Retrieved from http://www.norden.org/en/publications/publications_results_view?Se archablePublicationsText=Declaration+Nordic+language.

Nordic Council of Ministers (2018), on behalf of Frans Gregersen et al. More parallel, please!: Best practice of parallel language use at Nordic Universities: 11 recommendations. København: Nordisk Ministerråd. Retrieved from http://norden.divaportal.org/smash/record.jsf?pid=diva2\%3A1203291\&dswid=-7203.

O'Regan, J. P. (2014). English as a lingua franca: an immanent critique. Applied Linguistics, 35/5, 533-552.

Phillipson, R. (1992). Linguistic imperialism. Oxford: Oxford University Press. Phillipson, R. (1999). Voice in global English: unheard chords in Crystal loud and clear. Review article on 'English as a global language' by David Crystal. Applied Linguistics, 20/2, 288-299.

Phillipson, R. (2003). English-only Europe? Challenging language policy. London: Routledge.

Phillipson, R. (2006). English, a cuckoo in the European higher education nest of languages? European Journal of English Studies, 10/1, 13-32.

Phillipson, R. (2008). Lingua franca or lingua frankensteinia? English in European integration and globalisation. A 'Forum' with responses by seven scholars and a closing word by Robert Phillipson. World Englishes, 27/2, 250-284.

Phillipson, R. (2009). Linguistic imperialism continued. New York: Routledge.

Phillipson, R. (2011). Robert Phillipson responds to Humphrey Tonkin's Language and the ingenuity gap in science: The empire of scientific English. Critical Inquiry in Language Studies, 8/1, 117-124.

Phillipson, R. (2014). Americanization and Englishization as processes of global occupation. In P. W. Orelus (Ed.), Affirming Language Diversity in Schools and Society: Beyond linguistic apartheid (pp. 188-214). New York: Routledge.

Phillipson, R. (2015). English as threat or opportunity in European higher education. In S. Dimova, A. K. Hultgren \& C. Jensen (Eds.), English- 
medium instruction in higher education in Europe (pp. 19-42). Berlin: de Gruyter Mouton.

Phillipson, R. (2016a). Promoting English: Hydras old and new. In P. Bunce, R. Phillipson, V. Rapatahana, and R F. Tupas (Eds.), Why English? Confronting the Hydra (pp. 35-46). Bristol: Multilingual Matters.

Phillipson, R. (2016b.). Additive university multilingualism in English-dominant empire: the language policy challenges. In M. Langner and V. Jovanovic (Eds.), Facetten der Mehrsprachigkeit. Reflets du plurilinguisme (pp. 139-161). Bern: Peter Lang.

Phillipson, R. (2016c). Native speakers in linguistic imperialism. Journal of Critical Education Policy Studies, 14/3 (electronic).

Phillipson, R. (2016d). Myths and realities of 'global' English. Language Policy, $16 / 3,313-331$.

Piekkari, R. \& Westney, D. E. (2017). Language as a Meeting Ground for Research on the MNC and Organization Theory. In Multinational Corporations and Organization Theory: Post Millennium Perspectives (pp. 193-232). Published online: 20 Feb 2017. doi: 10.1108/S0733$558 \times 20160000049007$.

Skutnabb-Kangas, T. \& Phillipson R. (Eds.) (2017). Language Rights. Volume 1. Language rights: principles, enactment, application. London and New York: Routledge.

Skutnabb-Kangas, T. \& Phillipson R. (Eds.) (2017). Language Rights. Volume 2. Language policy in education: violations or rights for all? London and New York: Routledge.

Skutnabb-Kangas, T. \& Phillipson R. (Eds.) (2017). Language Rights. Volume 3. Language endangerment and revitalisation; language rights charters and declarations. London and New York: Routledge.

Skutnabb-Kangas, T. \& Phillipson R. (Eds.) (2017). Language Rights. Volume 4. Language rights: challenges in theory and implementation. London and New York: Routledge.

Skutnabb-Kangas, T. (2000). Linguistic genocide in education - or worldwide diversity and human rights? Mahwah, NJ: Lawrence Erlbaum.

Tonkin, H. (2011). Language and the ingenuity gap in science. Critical Inquiry in Language Studies, 8/1, 105-116. 
Trabant, J. (2012). Über die Lingua Franca der Wissenschaft. In H. Oberreuter, W. Krull, H. Joachim Meyer \& K. Ehlich (Eds.) Deutsch in der Wissenschaft. Ein politischer und wissenschaftlicher Diskurs (pp. 101107). München: Olzog Verlag.

\section{Robert Phillipson}

Kopenhagos verslo mokykla, Danija; rp.msc@cbs.dk

\section{GLOBALIOS IR REGIONINĖS INTEGRACIJOS METU KYLANTYS KALBOS IŠŠŪKIAI}

Santrauka. Straipsnyje analizuojama, ar anglu kalbos plètra papildo lingvistinius repertuarus, ar vis dèlto dèl jos yra atsisakoma nacionaliniu kalbu lingvistinio kapitalo. Taip pat yra tiriamas visuotinès anglu kalbos ir anglu kaip lingua franca kalbos diskursu vaidmuo globalioje ir regionineje Europos integracijoje. Straipsnyje svarstoma, ar ivairiu kalbu lingvistinis kapitalas išlieka produktyvus, kai didžioje dalyje Europos šaliu yra ženkliai mažiau mokomasi kitu užsienio kalbu nei anglu ir išlieka besitęsiantis mažumos kalbu nepaisymas. I kalbu pedagogika ir kalbos politika turi būti plačiau atsižvelgiama politiniame, socialiniame ir ekonominiame kontekste. ES bendradarbiavimo moksliniu tyrimu sritys ir studentu mobilumo schemos suteikia ribota pagalbą išsaugant lingvistinę ivairovę. Bolonijos procesas skatina Europos integracija, bet sustiprina anglu kalbos hegemonija. Šiaurès šaliu universitetai pereina i dvikalbę švietimo sistema, kurioje suderinama anglu ir nacionalinè kalbos. $2006 \mathrm{~m}$. Šiaurès šaliu kalbu politikos deklaracija siekiama užtikrinti, kad Šiaurès šaliu kalbos ir anglu kalba vystytusi lygiagrečiai, taip pat, kad visi gyventojai galètu išsaugoti savo kalba, o kalbos politikos iššūkiai būtu žinomi plačiajai visuomenei. Jei neoliberalizmas ir neoimperializmas yra lemiami veiksniai, tokiu atveju iškyla sunkumu išsaugant kalbu gyvybinguma ir organizuojant mokyklu ir universitetu švietima, kuris ugdytu kritiškai mąstančius daugiakalbius piliečius.

Pagrindinès sąvokos: Bolonijos procesas; ES; visuotinè anglu kalba; kalbos politika; lingua franca; daugiakalbyste; lingvistinis kapitalas; lingvistinis imperializmas; Šiaurès šaliu kalbos; Vinstonas Čerčilis. 